\title{
Pemrosesan Kecepatan dan Headway Lalu Lintas berdasarkan Video Images
}

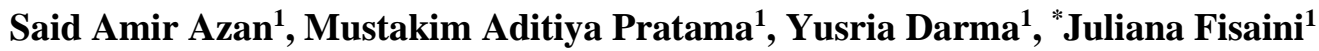 \\ ${ }^{1}$ Fakultas Teknik, Universitas Syiah Kuala, Kota Banda Aceh
}

\begin{abstract}
Vehicles' growth rate will influence the transportation problems becoming more complex in the future. It is believed that there will be more challenging if the traffic control remains rely on conventional management system. Therefore, it is essential to implement intelligent transportation system such as the use of video cameras in monitoring traffic on the highway. This study aims to develop a model which made in the Matlab Simulink software to obtain information on the targeted traffic parameters, such as vehicle speed and headway based on video images. Data used in this study is the record of traffic condition on Jalan T. Nyak Arief, Jeulingke, Banda Aceh on Saturday, June 20, 2020. Data are analyzed by using two methods to be precise, manual calculation and using Matlab Simulink software. The 4-5 minutes video are processed to obtain 30 vehicles per lane as the samples. By using the Mean Absolute Percentage Error (MAPE), the result shows that the level of accuracy obtained are $76.89 \%$ and $89.78 \%$ for vehicle speed and headway, respectively. In conclusion, the Matlab Simulink software is considered applicable to be used as a tool to process data from traffic video images.
\end{abstract}

Keywords: traffic, video images, speed, headway, Matlab Simulink

\begin{abstract}
ABSTRAK
Pertumbuhan jumlah kendaraan di masa yang akan datang berimplikasi pada permasalahan transportasi akan menjadi semakin kompleks, sehingga akan sulit jika pengendalian lalu lintas masih mengandalkan manajemen konvensional. Oleh karena itu, diperlukan penerapan sistem transportasi cerdas seperti penggunaan kamera video dalam pemantauan dan pengawasan lalu lintas di jalan raya. Penelitian ini bertujuan mengembangkan model program yang dibuat pada Software Matlab Simulink untuk mendapatkan informasi parameter lalu lintas tinjauan yaitu kecepatan dan headway berdasarkan video images sebagai implementasi penerapan sistem transportasi cerdas. Data yang digunakan pada penelitian ini ialah data rekaman lalu lintas pada ruas jalan T. Nyak Arief, Jeulingke, Kota Banda Aceh pada hari Sabtu, tanggal 20 Juni 2020. Pengolahan data dilakukan dengan dua metode yaitu perhitungan secara manual dan menggunakan Software Matlab Simulink. Sampel data yang diambil untuk perhitungan secara manual dan menggunakan software berjumlah 30 kendaraan per lajur dengan durasi video input yang digunakan sekitar $4-5$ menit. Berdasarkan hasil analisis, tingkat keakuratan dan persentase error dengan menggunakan Mean Absolute Percentage Error (MAPE), diperoleh tingkat keakuratan kecepatan sebesar 76,89\% dan untuk tingkat keakuratan headway diperoleh sebesar $89,78 \%$. Berdasarkan hasil yang didapat dapat diambil kesimpulan bahwa Software Matlab Simulink dapat digunakan untuk mengukur kecepatan dan headway.
\end{abstract}

Kata kunci: Sistem pemantauan lalu lintas, sistem transportasi cerdas, Matlab Simulink, $M A P E$

\section{Pendahuluan}

Pemantauan lalu lintas di Kawasan perkotaan kini telah dilakukan dengan menggunakan kamera atau menggunakan kamera surveillance (CCTV). Kondisi lalu lintas pada area pantauan dapat diakses atau diawasi dari

Journal of The Civil Engineering Student

Vol. 3. No. 2, Agustus 2021, Halaman 204-210 ruang server (workstation) oleh petugas. Upaya ini bertujuan untuk mengoptimalkan kinerja jalan pada lokasi-lokasi tinjauan. Namun demikian, di beberapa kota seperti Kota Banda Aceh, kamera surveillance tersebut belum dapat merekam kecepatan kendaraan dan 
headway antar kendaraan yang melewati suatu ruas jalan.

Penelitian ini bertujuan untuk mengembangkan model atau algoritma dengan menggunakan software Matlab Simulink untuk mendeteksi kecepatan lalu lintas dan headway antar kendaraan dengan menggunakan video images. Selain untuk memantau kondisi lalu lintas/kinerja jalan untuk keperluan kelancaran lalu lintas, pengembangan ini juga dapat dimanfaatkan untuk mempermudah survei lalu lintas dimana terdapat kebutuhan data parameter kecepatan dan Headway lalu lintas. Video yang digunakan merupakan video yang diperoleh dari kamare surveillance milik Dinas Perhubungan Kota Banda Aceh yang diletakkan pada Ruas Jalan T. Nyak Arief, Kota Banda Aceh.

Beberapa model telah dikembangkan untuk memproses gambar dari video untuk mendeteksi parameter-parameter lalu lintas. Azan \& Malahayati (2010) telah mengembangkan sistem pemantauan lalu lintas secara real time dengan perangkat lunak Matlab. Parameter-parameter yang dipantau adalah volume lalu lintas, kecepatan dan pengkelasan kendaraan. Namun demikian, tidak dijelaskan tingkat keakuratan model yang telah dikembangkan. Abbas (2013) juga telah mengembangkan model untuk menghitung kepadatan lalu lintas dengan menggunakan Matlab. Hasil pengembangan ini diklaim sangat efektif dalam penghematan biaya karena tidak membutuhkan foto udara ataupun sensor yang kompleks. Panda dkk (2015) juga kembali mengembangkan model serupa dengan Abbas (2013) dengan tujuan utama dapat memantau kepadatan lalu lintas pada suatu ruas jalan. Secara lebih rinci, Panda dkk menjelaskan tentang penerapannya dengan menghubungkan dengan Global System for Mobile communication (GSM) dimana model ini dapat dikembangkan penggunaannya untuk kendaraan darurat seperti mobil polisi, pemadam kebarakaran dan ambulan.

Secara umum kajian-kajian ini lebih berfokus kepada parameter kepadatan / volume lalu lintas pada ruas jalan. Untuk itu masih diperlukan pengembangan lebih lanjut seperti model untuk memproses parameter kecepatan dan headway dengan disertai perhitungan tingkat keakuratan model.

\section{Metode Penelitian}

\section{Lokasi Penelitian}

Lokasi pengambilan data lalu lintas pada penelitian ini diambil pada ruas Jalan T.Nyak Arief, Jeulingke Kota Banda Aceh. Lokasi ini dipilih dikarenakan terdapat kamera CCTV di bawah jembatan penyeberangan orang yang tepat di pertengahan ruas jalan yang ditinjau dan dapat memudahkan dalam pemrosesan analisis data, sehingga dalam pengambilan data lalu lintas tidak menganggu arus lalu lintas di ruas jalan tersebut.

\section{Peralatan}

Peralatan pendukung yang digunakan dalam penelitian ini adalah Komputer dengan minimal processor $2.40 \mathrm{GHz}$, RAM 2.00 GB, Kamera CCTV spek $30 \mathrm{f} / \mathrm{s}-60 \mathrm{f} / \mathrm{s}$. Adapun pada penelitian ini kamera CCTV yang digunakan yaitu kamera CCTV yang dimiliki oleh Dinas Komunikasi, Informatika dan Statistik Kota Banda Aceh dan Software MATLAB versi 7.5 yang bekerja dalam OS Windows.

\section{Metode Pengumpulan Data}

Data lalu lintas yang digunakan pada penelitian ini diambil pada siang hari, dimana keadaan arus lalu lintas di ruas jalan yang ditinjau tidak dipengaruhi oleh adanya bayangan. Hal ini dimaksudkan untuk memudahkan dalam merancang model sistem yang dibangun pada program Matlab SIMULINK. Apabila data rekaman dipengaruhi oleh bayangan, terkadang model sistem yang dibangun akan kesulitan dalam pendeteksian parameter yang ditinjau akibat adanya bayangan yang mungkin dihitung sebagai suatu kendaraan.

Alat yang diperlukan pada pengumpulan data ini diantaranya adalah alat ukur (meteran) dan kamera. Alat ini digunakan untuk mendapatkan jarak yang akan digunakan untuk penentuan daerah Region Of Interest (daerah yang diinginkan dalam proses pendeteksian 
kendaraan). Kamera digunakan untuk merekam video arus lalu lintas.

\section{Metode Pengolahan Data}

Pada penelitian ini, pengolahan data dilakukan dengan menggunakan program SIMULINK. Program ini merupakan bagian dari program MATLAB sebagai perangkat lunak untuk merancang sistem untuk pendeteksian parameter kecepatan dan headway lalu lintas. Secara garis besar sistem yang akan dibangun disajikan dalam dalam bentuk diagram blok yang ditunjukan seperti pada Gambar 1 . (Referensi)

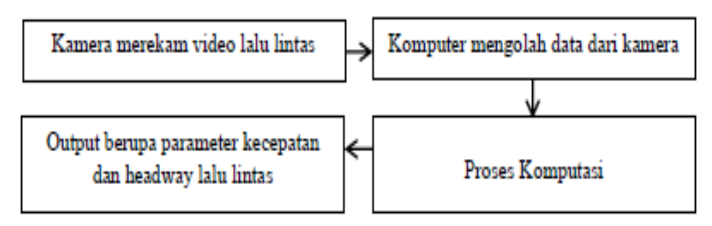

Gambar 1. Diagram blok sistem untuk pemantauan parameter lalu lintas

Selain melakukan pengolahan data dengan menggunakan Program Simulink, perhitungan data lalu lintas secara manual juga dilakukan. Tim penelitian menonton video hasil rekaman lalu lintas pada lokasi penelitian, kemudian mencatat data kecepatan dan headway kendaraan yang melintasi daerah pendeteksian.

Dalam penelitian ini, sistem yang digunakan dalam mendeteksi kendaraan dan parameter arus lalu lintas menggunakan titik - titik sensor yang diletakan di ruas jalan yang dilalui oleh kendaraan. Titik - titik sensor tersebut dibuat pada 2 garis imajiner dengan jarak kedua garis tersebut yaitu 10 meter yang digunakan untuk mengukur waktu tempuh dalam menghitung kecepatan kendaraan dan headway.

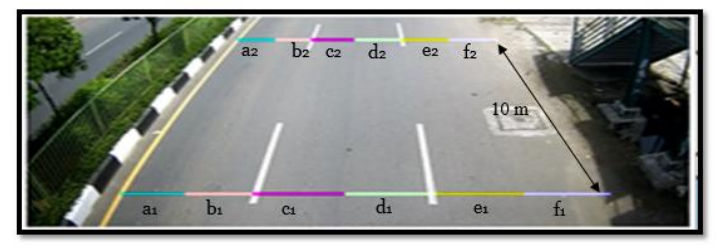

Gambar 2. Letak Garis Sensor pada software

a. Kecepatan
Untuk perhitungan kecepatan, analisis data secara manual dilakukan dengan mengamati waktu tempuh kendaraan yang melintasi antara 2 garis imajiner yang telah dibuat dengan menggunakan stopwatch, selanjutnya dilakukan kalkulasi dengan Microsoft Excel dengan perhitungan kecepatan berdasarkan rumus kecepatan yang terdapat pada tinjauan pustaka, dengan jarak yang digunakan yaitu 10 meter sesuai jarak sebenarnya di lapangan. Adapun perhitungan kecepatan pada penelian ini berdasarkan tiap tiap lajur ruas jalan yang ditinjau dengan hasil yang didapat yaitu rata - rata kecepatan dari tiap lajurnya.

Selanjutnya untuk perhitungan kecepatan dengan analisis menggunakan Software Matlab Simulink dilakukan dengan menetapkan jarak pada garis sensor pada software dengan jarak aktual 10 meter dengan waktu tempuh kendaraan yang melewati dua garis sensor. Garis sensor yang diletakkan dalam layar merupakan garis imaginer di dalam sistem yang dibnagun yang dilalui oleh kendaraan. Perhitungan waktu (t) akan dimulai ketika kendaraan menyentuh garis sensor 2 dengan garis sensor 1 sehingga kecepatan dapat diperoleh dan ditampilkan pada layar setelah sistem di run. Berikut tampilan gambar pengukuran kecepatan pada model sistem yang dibangun pada Matlab Simulink.

\section{Hasil dan Pembahasan}

\section{Hasil Pengolahan Data Secara Konvensional/Manual}

Ada dua parameter lalu lintas yang dihitung pada penelitian ini, yaitu parameter kecepatan dan parameter headway. Tabel 1 menunjukkan hasil pengolahan data kecepatan lalu lintas yang dilakukan secara manual/konvensional. Kecepatan rata-rata yang dihasilkan dari 30 sampel kendaraan dari tiap - tiap lajur sangat bervariasi. Pada lajur 1 (lajur cepat), kecepatan rata - rata yang diperoleh adalah sebesar 58,75 $\mathrm{km} / \mathrm{jam}$. Pada lajur 2 (lajur tengah), kecepatan rata - rata yang dihasilkan yaitu $56,02 \mathrm{~km} / \mathrm{jam}$. Sedangkan pada lajur 3 (lajur lambat), kecepatan rata - rata yang dihasilkan yaitu $38,16 \mathrm{~km} / \mathrm{jam}$. 
Tabel 1. Hasil Pengolahan Data Kecepatan Lalu Lintas pada tiap lajur secara manual

\begin{tabular}{|c|c|c|c|c|c|c|}
\hline \multirow{2}{*}{ No Kendaraan } & Jarak & Waktu Tempulh & Kecepatan & $\begin{array}{c}\text { Selang waktu } \\
\text { tiap kendaran }\end{array}$ & Kecepatan & \multirow{2}{*}{ Keterangan } \\
\cline { 2 - 7 } & $\mathrm{d}(\mathrm{m})$ & tdet) & $(\mathrm{m}$ det) & (det) & $(\mathrm{km} / \mathrm{jam})$ & \\
\hline 1 & 10 & 0.578 & 17.301 & 0 & 62.28 & Mobil \\
\hline 2 & 10 & 0.468 & 21.368 & 1 & 76.92 & Mobil \\
\hline 3 & 10 & 0.58 & 17.241 & 20 & 62.07 & Sepeda Motor \\
\hline 4 & 10 & 0.904 & 11.062 & 4 & 39.82 & Mobil \\
\hline 5 & 10 & 0.828 & 12.077 & 2 & 43.48 & Mobil \\
\hline
\end{tabular}

Parameter selanjutnya yang diamati adalah headway atau jarak antar kendaraan yang melaju pada ruas pengamatan. Berdasarkan data rekaman video yang diamati pada 30 sampel kendaraan, pada lajur 1 (lajur cepat) diperoleh rata-rata headway yaitu sebesar 5,07 detik, selanjutnya pada lajur 2 (lajur tengah) diperoleh rata-rata headway yaitu sebesar 3,00 detik dan pada lajur 3 (lajur lambat) diperoleh rata - rata headway sebesar 8,70 detik.

\section{Hasil Pengolahan Data Menggunakan Matlab Simulink}

\section{Kecepatan Lalu Lintas}

Pada perhitungan kecepatan tiap kendaraan di setiap lajur pada ruas jalan yang ditinjau pada Software Matlab Simulink, ROI dari potongan gambar video ditetapkan dalam suatu blok subsistem yang diproses menggunakan pasangan sensor garis. Dalam hal ini, digunakan garis 1 dan garis 2 untuk mendeteksi perubahan waktu. Perhitungan waktu dimulai saat suatu kendaraan di area yang diamati menyentuh garis pertama (garis 2) dan berhenti membaca setiap kali kendaraan menyentuh garis kedua (garis 1) dan terus berkelanjutan untuk setiap kendaran. Kecepatan pada Software Matlab Simulink dihitung dengan menggunakan persamaan pada Gambar 3.

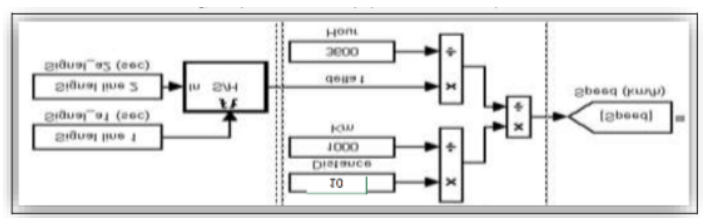

Gambar 3. Model Persamaan kecepatan

Jarak antara dua garis sensor yang digunakan sebagai titik acuan seperti yang ditunjukkan pada Gambar 4 adalah 10 meter pada jarak sebenarnya di lapangan. Untuk perhitungan software digunakan jarak antar garis sensor yang disesuaikan antara jarak sebenarmya di lapangan dengan pixel yang terdapat pada rekaman video yaitu jarak yang digunakan sebesar 10 meter. Kecepatan tiap kendaraan ditentukan oleh jarak antara dua jalur yang dilalui kendaraan dibagi dengan waktu yang ditempuh. Jarak antara dua garis sensor pada Software merupakan nilai yang telah ditentukan yang telah diukur dan dimasukkan ke dalam adegan gambar video.

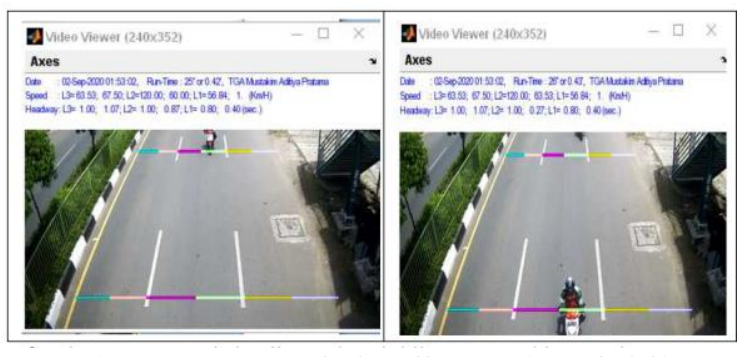

Gambar 4. Dua garis imajiner sebagai titik acuan perhitungan kecepatan

\section{(Sumber Matlab Simulink)}

Pada perhitungan kecepatan menggunakan Software ini juga dibuat model sistem yang digunakan untuk membuat perangkap kecepatan yang digunakan untuk menangkap kecepatan yang berada diatas batas kecepatan maksimum yang diatur pada Software Matlab Simulink. Algoritma yang digunakan dalam perhitungan perangkap kecepatan disajikan pada model sistem yang ditunjukkan pada Gambar 5.

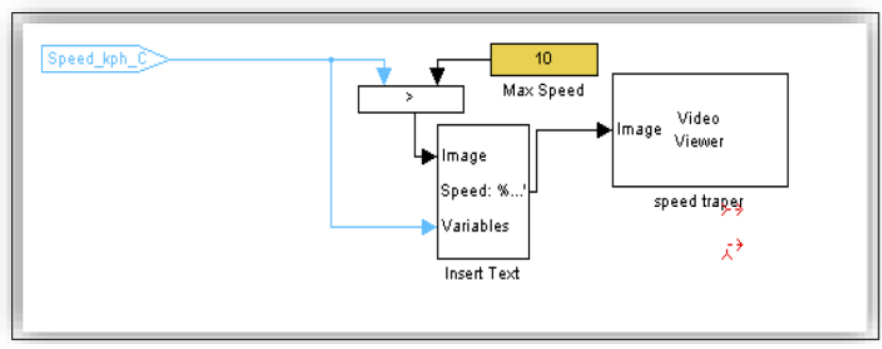

Gambar 5. Model sistem untuk menghitung perangkap kecepatan

\section{(Sumber: Matlab Simulink)}

Dalam sistem ini, ketika sinyal yang datang lebih tinggi daripada sinyal normal, sistem akan memotret kendaraan secara otomatis di area spresifik dalam adegan gambar video. Dalam gambar yang dipotret, nilai kecepatan disajikan di bagian atas gambar seperti yang ditunjukkan pada Gambar 6. 


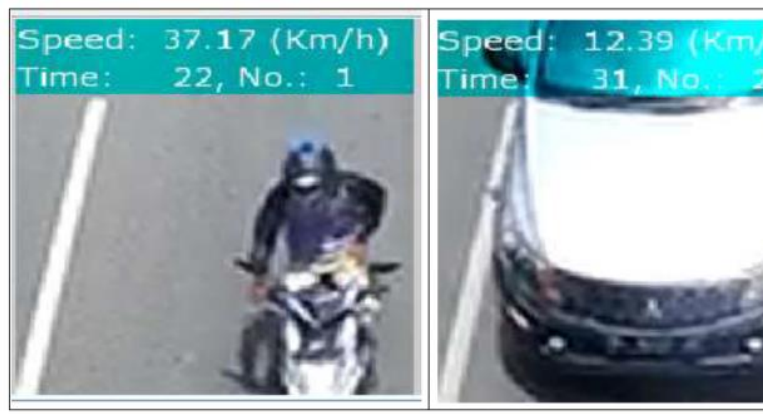

Gambar 6. Gambar potret perangkap kecepatan (Sumber Matlab Simulink)

Berdasarkan perhitungan kecepatan pada Software, pada lajur 1 diperoleh kecepatan rata - rata sebesar 50,82 km/jam, pada lajur 2 diperoleh kecepatan rata - rata sebesar 52,52 $\mathrm{km} / \mathrm{jam}$ dan pada lajur 3 diperoleh kecepatan rata - rata sebesar $44 \mathrm{~km} / \mathrm{jam}$.

Headway

Pada perhitungan Headway menggunakan Software, yang menjadi fokus pada model sistem ini adalah untuk mendeteksi objek pada garis sensor 1, yang pada perhitungan Headway ini, garis 1 tersebut merupakan garis referensi / acuan yang telah ditentukan sebelumnya di dalam adegan gambar video. Headway didefinisikan sebagai waktu kendaraan kedua mencapai garis acuan setelah kendaraan pertama mencapai garis acuan seperti yang ditunjukkan pada Gambar 4.9. Adapun perhitungan headway kendaraan pada software ini dihitung berdasarkan headway setiap kendaraan perlajurnya dan nilai headway juga disajikan dalam grafik signal headway yang ditunjukkan pada Gambar 7.

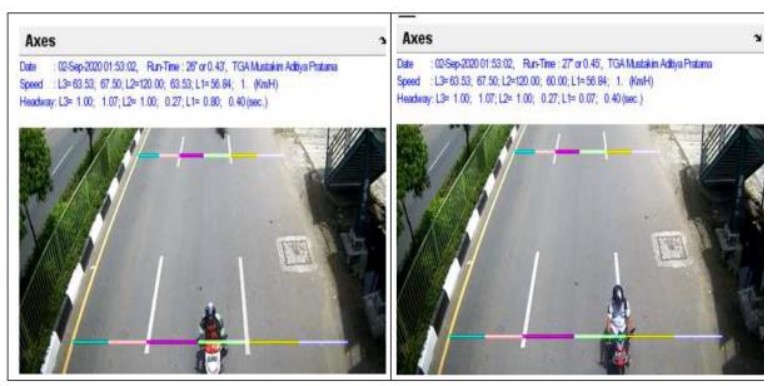

Gambar 7. Garis 1 sebagai garis acuan untuk perhitungan headway

(Sumber Matlab Simulink)

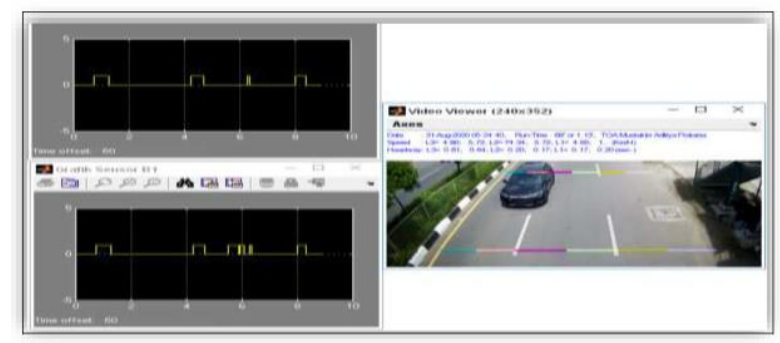

Gambar 8. Grafik signal headway tiap-tiap lajur

(Sumber: Matlab Simulink)

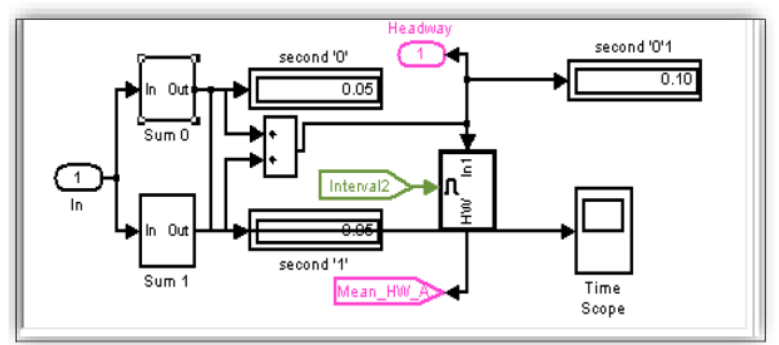

Gambar 9. Model sistem untuk menghitung

Headway dari tiap- tiap lajur

(Sumber: Matlab Simulink)

Model sistem yang digunakan dalam perhitungan headway menggunakan Software Matlab Simulink ditunjukkan pada Gambar 9. Berdasarkan perhitungan headway pada tiap lajur menggunakan Software Matlab Simulink dihasilkan rata - rata Headway pada lajur 1 diperoleh sebesar 4,13 detik, pada lajur 2 diperoleh sebesar 2,40 detik dan pada lajur 3 diperoleh sebesar 7,6 detik.

\section{Pembahasan}

Berdasarkan hasil pengolahan data, dilakukan analisis data sesuai dengan prosedur yang telah diuraikan pada bab metode pelaksanaan penelitian yaitu dengan membandingkan hasil pengolahan data kecepatan dan headway lalu lintas di ruas jalan T. Nyak Arief, Jeulingke, Kota Banda Aceh yang dilakukan secara manual/konvensional dengan hasil pemrosesan video rekaman lalu lintas dengan menggunakan software Matlab Simulink. Perbandingan ini dilakukan untuk mengetahui nilai error dan tingkat keakuratan dari model yang telah dibangun pada software Matlab Simulink. Asumsi yang digunakan adalah pengolahan data atau perhitungan yang 
dilakukan secara manual adalah data yang paling akurat.

Adapun hasil perhitungan kecepatan lalu lintas dan headway yang telah didapatkan dengan pengolahan data manual dan menggunakan software Matlab Simulink ditunjukkan pada Tabel 2 dan Tabel 3.

Tabel 2. Perbandingan tingkat keakuratan dalam Pengolahan Data Kecepatan

\begin{tabular}{|c|c|c|}
\hline \multirow{2}{*}{} & Kecepatan (km/jam) \\
\cline { 2 - 3 } & 4588.07 & Software \\
\hline Total & 203.63 & 4460.57 \\
\hline MSE & $(203,63 / 4588,07) * 100$ & 4.44 \\
\hline$\%$ Error & $100-4.44$ & 95.56 \\
\hline$\%$ Akurat & \multicolumn{2}{|c|}{} \\
\hline
\end{tabular}

Tabel 3. Perbandingan tingkat keakuratan dalam Pengolahan Data Headway

\begin{tabular}{|c|c|c|}
\hline \multirow{2}{*}{} & \multicolumn{2}{|c|}{ headway (s) } \\
\cline { 2 - 3 } & Manual & Software \\
\hline Total & 504.00 & 424.00 \\
\hline MSE & \multicolumn{2}{|c|}{10.27} \\
\hline$\%$ Error & $(10.27 / 504) * 100$ & 2.04 \\
\hline$\%$ Akurat & $100-2.04$ & 97.96 \\
\hline
\end{tabular}

Berdasarkan kedua tabel tersebut dapat dilihat perbandingan tingkat keakuratan dari hasil yang didapat. Parameter kecepatan di ruas Jalan T. Nyak Arief, Jeulingke, Kota Banda Aceh dapat dilihat bahwa nilai error adalah sebesar $4,44 \%$ atau tingkat keakuratan adalah sebesar 95,56\%. Untuk perhitungan Headway dapat dilihat bahwa nilai error adalah sebesar $2,04 \%$ atau tingkat keakuratannya adalah sebesar 97,96\%.

Berdasarkan analisis data baik secara perhitungan manual maupun menggunakan Software Matlab Simulink diperoleh rata - rata kecepatan dari tiap lajurnya dengan sampel pengujian dari tiap lajurnya yaitu 30 kendaraan ditunjukkan pada tabel berikut.

Tabel 4. Rata-rata kecepatan yang diperoleh

\begin{tabular}{|c|c|c|}
\hline \multirow{2}{*}{ Lajur } & \multicolumn{2}{|c|}{ Rata - Rata Kecepatan (km/jam) } \\
\cline { 2 - 3 } & Manual & Software \\
\hline 1 & 58,75 & 50,82 \\
\hline 2 & 56,02 & 52,52 \\
\hline 3 & 38,16 & 44.00 \\
\hline
\end{tabular}

Journal of The Civil Engineering Student

Vol. 3. No. 2, Agustus 2021, Halaman 204-210
Setelah dilakukan perhitungan untuk mendapatkan parameter lalu lintas yang ditinjau maka hasil dari perhitungan secara manual dan perhitungan menggunakan software selanjutnya dilakukan perbandingan untuk mengetahui nilai error serta tingkat keakuratan dari hasil yang telah didapat dengan menggunakan persamaan Mean Absolute Percentage Error (MAPE). Adapun hasil - hasil perhitungan kecepatan dan headway yang telah didapatkan dengan perhitungan manual dan menggunakan software Matlab Simulink ditunjukkan pada Tabel 3 dan Tabel 4 berikut.

Tabel 5. Perhitungan tingkat keakuran pengukuran kecepatan

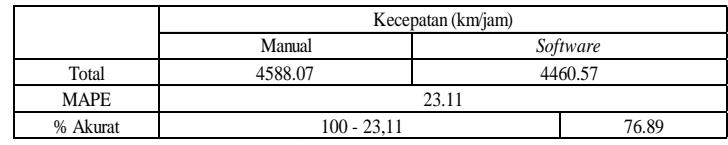

Tabel 6. Perhitungan tingkat keakuratan pengukuran headway

\begin{tabular}{|c|c|c|}
\hline \multirow{2}{*}{} & \multicolumn{2}{|c|}{ Headway (detik) } \\
\cline { 2 - 4 } & Manual & \multicolumn{2}{|c|}{ Software } \\
\hline Total & 505.00 & \multicolumn{2}{|c|}{10.22} \\
\hline MAPE & \multicolumn{3}{|c|}{$100-10.22$} & 89.78 \\
\hline \% Akurat & \multicolumn{2}{|c|}{} \\
\hline
\end{tabular}

\section{Kesimpulan dan Saran}

Berdasarkan hasil pengolahan data dan analisis data serta pembahasan yang telah diuraikan pada bab-bab sebelumnya, maka dapat dibuatkan kesimpulan dan saran tentang penggunaan video images dalam melakukan pemrosesan kecepatan lalu lintas dan headway dengan menggunakan program matlab Simulink ini.

\section{Kesimpulan}

Penggunaan teknologi informasi dalam bidang transportasi atau sistem transportasi cerdas dipercaya dapat memudahkan pekerjaan manusia di bidang transportasi. Pengembangan suatu program atau secara khusus Software Matlab Simulink secara umum dapat digunakan untuk menghitung kecepatan lalu lintas dan headway berdasarkan video images. Meskipun demikian, pada pemrosesan data kecepatan lalu lintas, tingkat keakuratan yang diperoleh adalah sebesar 95,56 \% atau 
mengalami error sebesar 4,44\%. Sedangkan dalam pemrosesan rekaman video headway diperoleh tingkat keakuratan sebesar 97,96\% atau error sebesar 2,04\%. Angka ini dapat dijadikan dasar konversi perhitungan parameter lalu lintas jika teknologi ini diaplikasikan dalam dikemudian hari.

\section{Saran}

Berdasarkan yang diperoleh, saran yang dapat diberikan untuk pengembangan program ini di masa yang akan dating adalah harapan agar penelitian ini dapat dilanjutkan dengan menggunakan Software Matlab Simulink untuk mengukur parameter arus lalu lintas yang lainnya. Selain itu, untuk dapat menjadikan hasil penelitian ini dapat diaplikasikan dalam kegiatan pekerjaan konsultasi bidang transportasi, penggunaan sampel dengan jumlah yang lebih besar akan dapat menjadi alternatif agar dapat diperoleh angka konversi keakuratan data

\section{Ucapan Terima Kasih}

Tim Peneliti mengucapkan terima kasih kepada semua pihak yang telah memberi dukungan pada penelitian ini, khususnya kepada Dinas Komunikasi, Informatika dan Statistika Kota Banda Aceh yang telah memberikan data rekaman lalu lintas pada ruas jalan yang ditinjau yang digunakan pada penelitian ini.

\section{Daftar Pustaka}

Abbas, N., Tayyab, M. and Qadri, M.T., 2013. Real time traffic density count using image processing. International Journal of Computer Applications, 83(9), pp.16-19.

Said Amir Azan dan Nurul Malahayati, 2010, Sistem Pemantauan Lalulintas Secara Automatik dan Real Time, Peran Serta Teknik Sipil Dalam Pembangunan Aceh, Procceding Seminar Ilmiah Tknik Sipil Ke-1, Banda Aceh, 20 Pebruari 2010, , Fakultas Teknik Universitas Syiah Kuala, , 2086-5244.

Panda, A., Naik, A. and Patel, P., 2015. Application of Image Processing In Road Traffic Control. International Journal of
Advanced Research Trends in Engineering and Technology (IJARTET), 2(4). 